\title{
Current Situation of Arabic Language Studies in Jordan Universities
}

\author{
Mohd Azidan Abdul Jabar', Zeyad Faisal Al-Azzam* \\ 1. Universiti Putra Malaysia, Malaysia \\ 2. World Islamic Science \& Education University, Jordan
}

How to cite this paper: Jabar, M. A. A., \& Al-Azzam, Z. F. (2017). Current Situation of Arabic Language Studies in Jordan Universities. The Educational Review, USA, 1(4), 94-100.

http://dx.doi.org/10.26855/er.2017.04.003

Corresponding author: Zeyad Faisal AlAzzam, World Islamic Science \& Education University, Jordan.

\begin{abstract}
Hashemite Kingdom of Jordan is often considered one of the most popular educational hubs for Middle East and North Africa (MENA) region. Although the country is small in size and population, but it is big in its agenda to develop its higher education system. It has a substantial number of higher education institutions that offer various academic programs. One of its most sought after programs by foreign students especially from Malaysia are Arabic Language and Studies. The number of Malaysian students taking Arabic programs in Jordan is increasing every year. On the same note, we find in Malaysian that many Arabic teachers and scholars are the graduates of universities in Jordan. They have been doing their role in developing Arabic language teaching and learning programs and modules in educational institutions in Malaysia. This paper will look briefly at the overall situations of Arabic language programs offered by public universities in Jordan and to show how our Malaysian institutions could benefit from Jordan experience in developing its national language in higher education institutions.
\end{abstract}

\section{Keywords}

Arabic Language, Universities in Jordan, Programs, Malaysian Institutions

\section{Introduction}

Arabic language is an official language of 22 countries in the Middle East and North Africa (MENA) region and is currently used by more than 350 million people across the world including of people who are residing outside the region. Jordan which is strategically located in the middle of MENA region and has a substantial number of higher education institutions and scholars is always regarded as a source of reference when it comes to higher educational studies in various fields among Arab countries. Jordan has a great mission to become educational hub for the region. Jordan Ministry of Higher Education and Scientific Research (MOHESR) and Ministry of Education are gearing up to improve the quality of study and education in Jordan and currently are taking steps and measures to bring the country to the next level of educational growth and excellence.

This is resulted in the flocking of foreign students into Jordan universities to pursue their higher education including from Malaysia. One of the reasons why students from Malaysia and other Asian countries are coming to Jordan universities is for them to learn Arabic language. In their views, universities in Jordan offer better quality of teaching and learning and reach a standard of any reputable universities in the world. In addition to this, the internal surroundings of the country have created a very conducive and helpful learning situation of Arabic language. Malaysian Government has been sending students to Jordanian universities since the 1990s and the outcome is very fruitful to the development of 
Arabic language in Malaysia where graduates from Jordan are playing a pivotal role in developing Arabic language in their home country.

Much has been said about this country that promotes Arabic language intensively and extensively through its teaching and learning of the language in higher education institutions. Hence, it is good for higher education institutions in Malaysia to learn some experience from Jordan in order to improve its similar Arabic programs that are offered in local universities.

\section{Importance of Arabic Language Programs}

Chijne (1969) stated that Arabic has played and is still playing an important role in the history and in the improvement of Arabs and Muslims (Abu Irmies, 2014). In addition, it is a liturgical language which used to recite the Noble Quran and in prayer. It is also required from every Muslim no matter what his native tongue is Arabic has also helped largely to preserve cultural unity and continuity in the Muslim world, and has registered the accomplishments of the Arab Muslim peoples. Muslims and Arabs believe that Arabic is a God given language, single in beauty and majesty and the most meaningful of all languages for expressing ideas and feelings (Abu Irmies and Dweik, 2015).

Arabic is becoming an important language in all fields; as a result, learning it opens up many employment possibilities in a number of fields. Thus, there are many reasons which motivate a lot of learners from different parts of the world to learn Arabic. Some learners learn Arabic as part of their academic work. However; others learn Arabic to know about the cultures of the Arabic language. Moreover, learners of Arab origin often learn Arabic to understand the Arabic heritage and to attain familiarity with the language of their ancestor's. Furthermore, Muslim learners learn Arabic to be able to read and understand the Holy Quran and Hadith (Abu Irmies, 2014). Additionally, with new modern technological and social networks advancements, Arabic Language faced too many difficulties that brought issues of the effectiveness and efficient of Arabic Language studies (programs) offered by universities, hence, Jordan universities starts working on them to provide students with skills and abilities to listen, read, and speak fluently. Therefore, comprehensive revisions of Arabic Language programs have been refreshing regularly to be in line with new developments occurring around (AlWaely et al, 2011).

However, it must be admitted that acquiring such intimate and indepth knowledge of Arabic is no small task. Learning Arabic can be moderately hard to be learned if the person doesn't have the right mindset. She/he should always try to maximize her/ his resources and time for the best learning experience possible. It is difficult for a native speaker of Arabic, and this difficulty is multiplied for someone who is not a native speaker. A student who wishes to become fully fluent in Arabic before embarking upon the study of the various branches of Islamic knowledge (or even Arabic Language) may never find the time to do so. The study of Arabic, as experience has shown, can take a considerable amount of time. In consideration of these facts, Jordan may be becoming a truly bilingual community at least in the capital Amman and primarily among the young generation who are mostly students. Perhaps this comes as a result of modernization and worldwide globalization and impact of rapidly spreading communication technology (Bani-Khaled, 2014). The question here is what are the impacts of Arabic diglossia, if any, on the experience of learners of Arabic for native speakers and as a foreign language? Therefore, universities of Jordan have started to review the core Arabic curriculum at their programmes and language institutions to find the extent to which these institutions are preparing their students to communicate effectively in the Arabic speaking world and to raise up the interest in Arabic as a mother tongue (Hashem-Aramouni, 2011; Al-Mamari, 2011; Bani-Khaled, 2014; Sakho, 2012; Murad, 2007). 


\section{Arabic Studies Programs}

Apparently, Arabic Language programs offered by universities of Jordan are designed and developed not only to overcome any challenges that might face it, but to equipped students with scientific qualifications, enriching them with higher quality knowledge of expertise and moreover, strengthening Arab and Islamic and human values among students, and to create ways of creativity and innovation. Therefore, universities of Jordan have put a flexible and an impressive program in Arabic Language Studies encompasses Bachelor, Master, and Doctorate degrees. In order to succeed, all universities in Jordan employ academic staff includes professors who indeed highly qualified, holding their Ph.D. degrees from Arab, European and American universities, thus achieving a great degree of diversity and integration, besides there also has a few M.A. and Ph.D. students studying abroad and they will return soon as teachers.

\section{Bachelor Degree Program}

At bachelor degree, almost all universities offered Arabic certificate where students who are going to study it, they should complete 132 credit hours consist of 44 subject. By and large, Department of Arabic Language in any university in Jordan offers a bachelor degree on completion of the following requirements (Table 1).

First: The University Requirements, allocated as follow:

1) Obligatory University course requirements.

2) Elective University course requirements.

Second: The Faculty Requirements, it depends on the faculty council to decide how many credit hours required which is different from one university to another. In general, some universities never divide them but others do into the following:

1) Obligatory Faculty of Arts requirements.

2) Elective Faculty of Arts requirements.

Third: Departmental (Specialization) course requirements: also there is variation in terms of credit hours that should be accomplished to be awarded the degree. As aforementioned, some universities never divide these courses whether obligatory or elective but others they do. According to universities, the degree can be also divided into the followings:

Single specialization course requirements, which in turn can be divided into the followings:

A. Obligatory courses.

B. Elective Courses.

C. Courses from other Departments.

Major/Minor specialization course requirements, which in turn can be divided into the followings:

A. Obligatory courses.

B. Elective Courses.

C. Courses from other Departments.

Indeed, the Ministry of Higher Education and Scientific Research, Jordan imposed on universities in Jordan to implement the university competency exam as a prerequisite for graduation. This exam is able to evaluate the all universities programs, subjects, materials, and quality of education, teachers, and students' knowledge in order to evaluate the whole programs to ensure quality at all levels. 
Table 1. Bachelor program in arabic language.

\begin{tabular}{|c|c|c|c|c|c|c|c|c|}
\hline \multirow[b]{2}{*}{ University } & \multicolumn{2}{|c|}{$\begin{array}{c}\text { University } \\
\text { Requirements }\end{array}$} & \multicolumn{2}{|c|}{$\begin{array}{c}\text { Faculty } \\
\text { Requirements }\end{array}$} & \multicolumn{3}{|c|}{ Departmental Requirements } & \multirow[b]{2}{*}{ Total Credit Hours } \\
\hline & 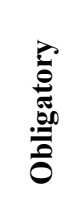 & 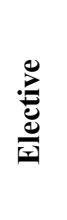 & 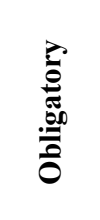 & 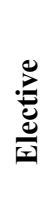 & 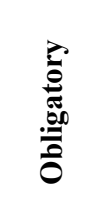 & 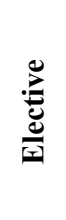 & 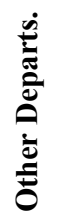 & \\
\hline University of Jordan & 21 & 6 & 24 & 0 & 60 & 21 & 0 & 132 \\
\hline Yarmouk University & 21 & 6 & 15 & 3 & 26 & 12 & 6 & 132 \\
\hline Mu'tah University & 12 & 15 & 9 & 12 & 69 & 18 & 0 & 135 \\
\hline Al al-Bayt University & 27 & 0 & 21 & 0 & 69 & 12 & 3 & 132 \\
\hline $\begin{array}{l}\text { Al-Hussein } \quad \text { Bin } \quad \text { Talal } \\
\text { University }\end{array}$ & 12 & 15 & 15 & 6 & 69 & 15 & 0 & 132 \\
\hline Tafila Technical University & 12 & 15 & 15 & 6 & 72 & 12 & 0 & 132 \\
\hline Al-Balqa'a Applied University & 21 & 6 & $18-30$ & 0 & $63-69$ & $3-9$ & 0 & 132 \\
\hline Hashemite University & 12 & 15 & 21 & 0 & 66 & 15 & 3 & 132 \\
\hline
\end{tabular}

Source: by authors based on Universities prospectus 2015

\section{Master Degree Program}

The Master Program in Arabic Language and Literature at Universities of Jordan aims to provide students with an advanced level of knowledge in their field of study and has been designed to facilitate the highest degree of in-depth research. At the same time, the program is flexible enough to provide students with the opportunity to focus on fields of the Arabic that complement their research interests, be they in the linguistic aspects of the Arabic language or in its vast literary and critical domains. Scientific research is of great importance in this program and is an integral part of knowledge acquisition in all course requirements. Hence, courses on the various methods of research writing are offered to students in order to enrich their theoretical and practical skills for writing academic papers (University of Petra Website, https://www.uop.edu.jo/En/Academics/FacultyofArtsandSciences/Pages/MasterOfArabicLanguge.aspx/).

The program's academic plan was designed to include two tracks (Table 2: Obligatory and elective credit hours for master program):

1) A dissertation track: which requires the completion of 33 credit hours, 24 of which go towards the completion of obligatory and elective coursework, and 9 credit hours of which are for the completion of a dissertation under the supervision of a faculty member from the Arabic Department.

2) A comprehensive examination track: which requires the completion of 33 credit hours, 24 of which go towards the completion of obligatory, and 9 credit hours of which go towards the completion of elective coursework, and at the end, passing the compulsory comprehensive exam to be awarded the degree.

Noteworthy, these coursework differently titled but the same content such as The Ancestors Methods in Characterizing the Arabic, Issue of the Umayyad Literature, The Methods of Modern Literary Criticism, Language and Literature 
Editing of Text, Arabic syntax Theory, Issue of Jahili (pre-Islamic)poetry, Specimens of The Abbaside prose, Arabic lexicon and Idiom, Specimens of Modern and contemporary Arabic Prose, The Arab phonetic Heritage, The Aspects of modern Linguistic Study, The Methods of Editing Manuscripts, Literary Texts in Foreign Language, A Seminar in Quranic Texts \& Methodology of Interpretation, Rhetoric in the light of Modern Criticism and so on.

Table 2. Obligatory and elective credit hours for master program.

\begin{tabular}{lcccc}
\hline \multirow{2}{*}{ University } & \multicolumn{4}{c}{ Master Program } \\
\cline { 2 - 5 } & Obligatory Courses & Elective Courses & Dissertation & Total \\
\hline Yarmouk & 15 & 9 & 9 & 33 \\
Jordan & 15 & 9 & 9 & 33 \\
Hashemite & 15 & 9 & 9 & 33 \\
Al-Hussein Bin Talal & 18 & 6 & 9 & 33 \\
Al Al-Bayt & 18 & 6 & 9 & 33 \\
Mu'tah & 15 & 9 & 9 & 33 \\
\hline
\end{tabular}

Source: by authors based on Universities prospectus 2015.

\section{Master Degree Program}

The issue of the administration and management of Arabic Language programs are subject to different pressures and challenges than those of other languages. In general, the dean's council at every university has decided to establish a new doctorate program in Arabic language and other sub-major topic in Arabic Language to provide the market with qualified doctors who are more capable to further educate a good an qualified people required by market at all jobs and levels, in addition to understand Islamic values, heritage, and holy Quran to better worship Allah. Meanwhile, most of universities take the burden to direct these programs to non-native speakers whether they are Muslims or not for two purposes; first, is to educate the Muslims from all over the world and equipped them with high quality of reading, writing, speaking Arabic Language to better understand the holy Quran and Islamic teachings and to become a messenger to educate other Muslims in their homeland. Second, is to explore and clarify the bad image about Islam and Islamic people in the world and convey the utmost Islamic values and ethics in dealing with others regardless of their religion.

Universities of Jordan established different PHD programs in Arabic Language, which imposed on whose who are going to be eligible to entertain program hold a Master degree in Arabic Language and Literature with a minimum very good average in addition to National English Exam that proof he is capable to listen, read, and speak English well. The study plan of this program requires studying 54 credit Hours divided on obligatory and elective courses as per follow (Table 3: Obligatory and elective credit hours for PHD program).

Obligatory Courses, it different from university to another on how many credit hours should be taken but at least every candidate should cover the obligatory courses where later will be sit for competency exam that qualified him/her to be PHD candidate and capable to write dissertation.

Elective Courses, also it is different from one university to another on how many credit hours should be taken, but at least it covers 15 credit hours in the minimum.

Proficiency Exam, upon the completion of all obligatory credit hours, the student will attend competency exam to discover whether he/she capable to proceed to write the dissertation or not. If he/she passed, then can start his/her dissertation proposal with discussions. 
Table 3. Obligatory and elective credit hours for PHD program.

\begin{tabular}{lcccc}
\hline \multirow{2}{*}{ University } & \multicolumn{3}{c}{ PHD Program } \\
\cline { 2 - 5 } & Obligatory Courses & Elective Courses & Dissertation & Total \\
\hline Yarmouk & 21 & 15 & 18 & 54 \\
Jordan & 18 & +18 & 18 & 54 \\
Al Al-Bayt & 21 & 15 & 18 & 54 \\
Mu'tah & 21 & 15 & 18 & 54
\end{tabular}

Source: by authors based on Universities prospectus 2015 .

\section{Conclusion}

Based on the facts and figures that is presented above, we can conclude that universities in Jordan offer Arabic programs which are complying with the standard of quality set by Jordan Ministry of Higher Education and Scientific Research (MOHESR). Universities are reviewing its programs from time to time to include new elements, issues and subjects in teaching and learning of Arabic language so that the programs remain competitive and attractive to all stakeholders. The updating and upgrading exercise of Arabic programs at all levels is always needed to ensure that the programs can compete with other languages especially English language programs. Hence, it is a big challenge for those universities in Jordan especially in the current situation where Arabs are also keen to learn other languages and have the courage to master English language. For Malaysian higher education institutions who offer similar programs, it is good for the Arabic programs here to learn from the Jordanian methods and models especially in terms of credit numbers, curriculum structure, course content and methods of delivery.

\section{References}

Abu-Irmies, \& Amani, J. (2014). Difficulties of Teaching Arabic to Speakers of Other Languages in Jordan. Master Thesis, Middle East University, Jordan.

Abu-Irmies, A., \& Dweik, B. (2015). Learning Arabic Language Culture by Speakers of Other Language. International Journal of Education Learning and Development, 3(3), 109-119.

Al-Jaradat, O., Al-Dwairi, K., \& Obeidat, O. (2014). The Role of Digital Library in Bridging the Language Divide: Comparison Study of Arabic and Other Languages. Information and Knowledge Management, 4(12), 106-122.

Al-Mamari, H. (2011). Arabic Diglossia And Arabic as A Foregn Language: The Perception of Students in World Learning Oman Center. Capstone Collection, 2437.

Al-Waely, et al. (2011). Perception of Arabic Language Teachers' of Their Competences and Usage of Integration Technology in Jordanian Schools. 11th International Educational Technology Conference, I. Istanbul-Turkey, 790-804.

Bani-Khaled, \& Turki, A. A. (2014). Attitudes towards Standard Arabic: A Case Study of Jordanian Undergraduate Students of English. International Journal of Linguistics, 6(4), 154-171.

Chejne, A. (1969). The Arabic Language: Its Role in History. UK: Oxford University Press.

Hashem-Aramouni, E. (2011). The Impact of Diglossia on Arabic Language Instruction in Higher Education: Attitudes and Experiences of Students and Instructors in the U.S. Ph.D Dissertation: Unpublished. California State University, Sacramento.

Khader, F. (2012). The Malaysian Experience in Developing National Identity, Multicultural Tolerance and Understanding through Teaching Curricula: Lessons Learned and Possible Applications in the Jordanian Context. International Journal of Humanities and Social Science, 2(1), 270-288.

Murad, M. (2007). Language Attitudes of Iraqi Native Speakers of Arabic: A Sociolinguistic Investigation. Master Thesis: Unpublished. The University of Kansas. 
Othman, E., Shaalan, K., \& Rafea, A. (2003). A Chart Parser for Analyzing Modern Standard Arabic Sentence, Proceedings of the MT Summit IX Workshop on Machine Translation for Semitic Languages: Issues and Approaches, USA. Accessed May 2005. http://www2.cs.cmu.edu alavie/semitic-MT-wshp.html.

Sakho, M. (2012). Teaching Arabic as a Second Language in International School in Dubai, a Case Study Exploring New Perspectives in Learning Materials Design and Development. Master Thesis: Unpublished. The British University in Dubai, $144-139$.

Shaalan, K. (2005). An Intelligent Computer Assisted Language Learning System for Arabic Learners. Computer Assisted Language Learning, 18(1\&2): 81-108.

Wahba, K., Taha Z., \& England, L. (2013). Handbook for Arabic Language Teaching Professionals in the 21st Century. Lawraence Erlbaum Associates Inc, Publishers: New Jersey. 